\title{
Comparison of high protein and high fiber weight-loss diets in women with risk factors for the metabolic syndrome: a randomized trial
}

\author{
Lisa A Te Morenga ${ }^{1,4^{*}}$, Megan T Levers ${ }^{1,4}$, Sheila M Williams², Rachel C Brown and Jim Mann ${ }^{1,3,4}$
}

\begin{abstract}
Background: Studies have suggested that moderately high protein diets may be more appropriate than conventional low-fat high carbohydrate diets for individuals at risk of developing the metabolic syndrome and type 2 diabetes. However in most such studies sources of dietary carbohydrate may not have been appropriate and protein intakes may have been excessively high. Thus, in a proof-of-concept study we compared two relatively low-fat weight loss diets - one high in protein and the other high in fiber-rich, minimally processed cereals and legumes - to determine whether a relatively high protein diet has the potential to confer greater benefits.

Methods: Eighty-three overweight or obese women, 18-65 years, were randomized to either a moderately high protein (30\% protein, $40 \%$ carbohydrate) diet (HP) or to a high fiber, relatively high carbohydrate $(50 \%$ carbohydrate, > $35 \mathrm{~g}$ total dietary fiber, 20\% protein) diet (HFib) for 8 weeks. Energy intakes were reduced by 2000 - $4000 \mathrm{~kJ}$ per day in order to achieve weight loss of between 0.5 and $1 \mathrm{~kg}$ per week.

Results: Participants on both diets lost weight (HP: $-4.5 \mathrm{~kg}$ [95\% confidence interval (Cl):-3.7, $-5.4 \mathrm{~kg}$ ] and HFib: -3.3 kg [95\% Cl: $-4.2,-2.4 \mathrm{~kg}]$ ), and reduced total body fat (HP: $-4.0 \mathrm{~kg}$ [5\% Cl:-4.6, $-3.4 \mathrm{~kg}]$ and HFib: $-2.5 \mathrm{~kg}$ [95\% Cl: -3.5 , $-1.6 \mathrm{~kg}]$ ), and waist circumference (HP: $-5.4 \mathrm{~cm}[95 \% \mathrm{Cl}:-6.3,-4.5 \mathrm{~cm}]$ and HFib: $-4.7 \mathrm{~cm}[95 \% \mathrm{Cl}:-5.8,-3.6 \mathrm{~cm}]$ ), as well as total and LDL cholesterol, triglycerides, fasting plasma glucose and blood pressure. However participants on HP lost more body weight $(-1.3 \mathrm{~kg}[95 \% \mathrm{Cl}:-2.5,-0.1 \mathrm{~kg} ; \mathrm{p}=0.039])$ and total body fat $(-1.3 \mathrm{~kg}[95 \% \mathrm{Cl}:-2.4,-0.1 ; \mathrm{p}$ $=0.029]$ ). Diastolic blood pressure decreased more on HP $(-3.7 \mathrm{~mm} \mathrm{Hg}[95 \% \mathrm{Cl}:-6.2,-1.1 ; \mathrm{p}=0.005])$.
\end{abstract}

Conclusions: A realistic high protein weight-reducing diet was associated with greater fat loss and lower blood pressure when compared with a high carbohydrate, high fiber diet in high risk overweight and obese women.

\section{Background}

Debate continues regarding the most appropriate macronutrient composition for achieving weight loss and improvement in risk factors for cardiovascular disease (CVD) and diabetes in overweight and obese individuals $[1,2]$. The "standard" low fat high carbohydrate (LFHC) approach, long recommended because of its cardio-protective potential, has been repeatedly challenged during the past decade by proponents of Mediterranean type diets [3], high fat diets [4-6] and more recently high protein diets (e.g. Zone [7], CSIRO Total Wellbeing diet [8]). Those advocating these alternatives to the LFHC

\footnotetext{
* Correspondence: lisa.temorenga@otago.ac.nz

1 Department of Human Nutrition, University of Otago, PO Box 56, Dunedin 9054, New Zealand

Full list of author information is available at the end of the article
}

approach have generally claimed greater weight reduction and or more favorable metabolic profiles [9]. Given that many who are overweight and obese have risk factors associated with the metabolic syndrome, the potential of high protein diets to reduce triglyceride concentrations and blood pressure while maintaining HDL cholesterol levels is regarded as being especially relevant [10].

The findings of trials that have compared high protein and LFHC diets have not been entirely consistent. Some, which have suggested a more favorable response to high protein have utilized LFHC comparison diets have included relatively high intakes of refined grains, starchy vegetables and sugars [11-14]. This is inappropriate since the benefits of high carbohydrate diets have only been observed when most dietary carbohydrate has been derived from fiber-rich wholegrain 
cereals, pulses, vegetables and fruit [15]. Other studies have used amounts of protein which would have been impractical for long term consumption $[16,17]$ or have only demonstrated benefit in subgroups such as those with elevated triglyceride concentrations [18] or women [19]. Thus, in a "proof of concept" study, we have compared a diet high in protein (HP) with one high in fiberrich, minimally processed cereals and legumes (HFib) to determine whether acceptable high protein diets have the potential to confer greater benefits.

\section{Methods}

Women aged 18-65 years with a body mass index (BMI) $\geq 27 \mathrm{~kg} / \mathrm{m}^{2}$ wishing to lose weight were recruited via advertisement in a local newspaper. Potential participants were screened during a telephone interview to determine eligibility, commitment to a nutrition-focused weight-loss program and existence of exclusion criteria. Potential participants were excluded if heart disease, cancer or kidney disease had been diagnosed; if they were taking medications influencing appetite and weight control; if they had participated in a weight loss program or had lost more than $1 \mathrm{~kg}$ bodyweight in the previous two months; or if they were pregnant, planning a pregnancy or breastfeeding. On the basis of the telephone call eighty-seven participants were invited to attend a screening visit during which a questionnaire relating to personal, demographic and health details was completed. The study protocol, risks and benefits were explained to each subject and written consent was given. The study was approved by the University of Otago Human Ethics Committee.

Two women did not meet the inclusion criteria and two withdrew before being randomized, thus 83 women were randomly assigned to treatment. One participant withdrew early because of unrelated surgery, two moved away and six others (4 on HP and 2 on HFib) opted out of the intervention and were lost to follow-up. Seventyfour women ( $89 \%$ of those randomized) completed the entire study (Figure 1).

The study involved an 8-week randomised, controlled, partially blinded dietary intervention. Participants were randomly assigned to either a high protein (HP) or a high fiber, high carbohydrate (HFib) energy-restricted diet using sequentially numbered, sealed envelopes containing a computer-generated allocation using random length blocks and stratified by age and BMI. Laboratory staff and those conducting dual X-ray absorptiometry (DXA) scans were unaware of group allocation but participants and those involved in the dietary intervention or making clinical measurements could not be blinded regarding group allocation.

The HP diet was based on the CSIRO Total Wellbeing diet [8] in which approximately $30 \%$ of total energy (TE) is derived from protein, and 40\% TE from carbohydrate. The HFib diet was designed to achieve at least 50\% TE from carbohydrate, $20 \%$ TE from protein, and $35 \mathrm{~g}$ or more dietary fiber daily with emphasis on wholegrains and legumes. Total and saturated fat intakes were intended to be below $30 \%$ and $10 \%$ TE respectively. Energy intakes were designed to achieve weight loss of $0.5-1.0 \mathrm{~kg}$ per week requiring an energy deficit on both diets of approximately $2000-4000 \mathrm{~kJ}$ per day but with total energy of more than $5500 \mathrm{~kJ}$ per day to ensure adequate nutrient intakes.

Dietary instruction was centered on advice regarding the number of standard servings of key food groups to be eaten each day utilising exchange lists. The basic diet plan for the HP group recommended three 100 g servings of lean protein foods and three servings of breads, cereals or grains per day. The basic diet plan for the HFib group recommended one $100 \mathrm{~g}$ serving of lean protein foods, six servings of wholegrain breads, cereals or grains per day and one serving of legumes. Both diet groups received the same recommendations with regard to fruit, vegetable, and fat/oils servings (Table 1). The basic diet plans were individually tailored by adjusting the number of servings of major food groups to achieve the desired level of weight loss while maintaining the appropriate macronutrient composition, taking into account a participant's estimated basal metabolic rate and confidence to reduce energy intake. Participants were required to complete a daily food group checklist in order to maintain adherence to macronutrient and energy intake goals. The HFib group was also asked to estimate their daily fiber intakes using a simple fiber calculator and to aim for an intake of $40 \mathrm{~g}$ per day by selecting high-fiber breads, cereals, fruits, vegetables, nuts and legume choices. To encourage compliance to the dietary regime participants on the HFib diet were provided with six servings per day of key high carbohydrate foods including wholegrain bread, wholegrain cereal, bran cereal, rye crackers and canned legumes. The HP group was provided with grocery vouchers equivalent in value to the food items received by the HFib group. They were instructed to use the vouchers to purchase lean protein foods such as lean meat, fish and chicken and to keep their receipts as proof of purchase. Both groups were given material especially prepared for this study, including checklists, recipes and menu plans. Participants met with nutritionists at randomization and every 2 weeks throughout the study to encourage dietary adherence. At these sessions participants were weighed, daily food group checklists were reviewed and strategies for maintaining adherence to the dietary advice were discussed. Participants were asked to maintain their usual levels of exercise for the duration of the study. 


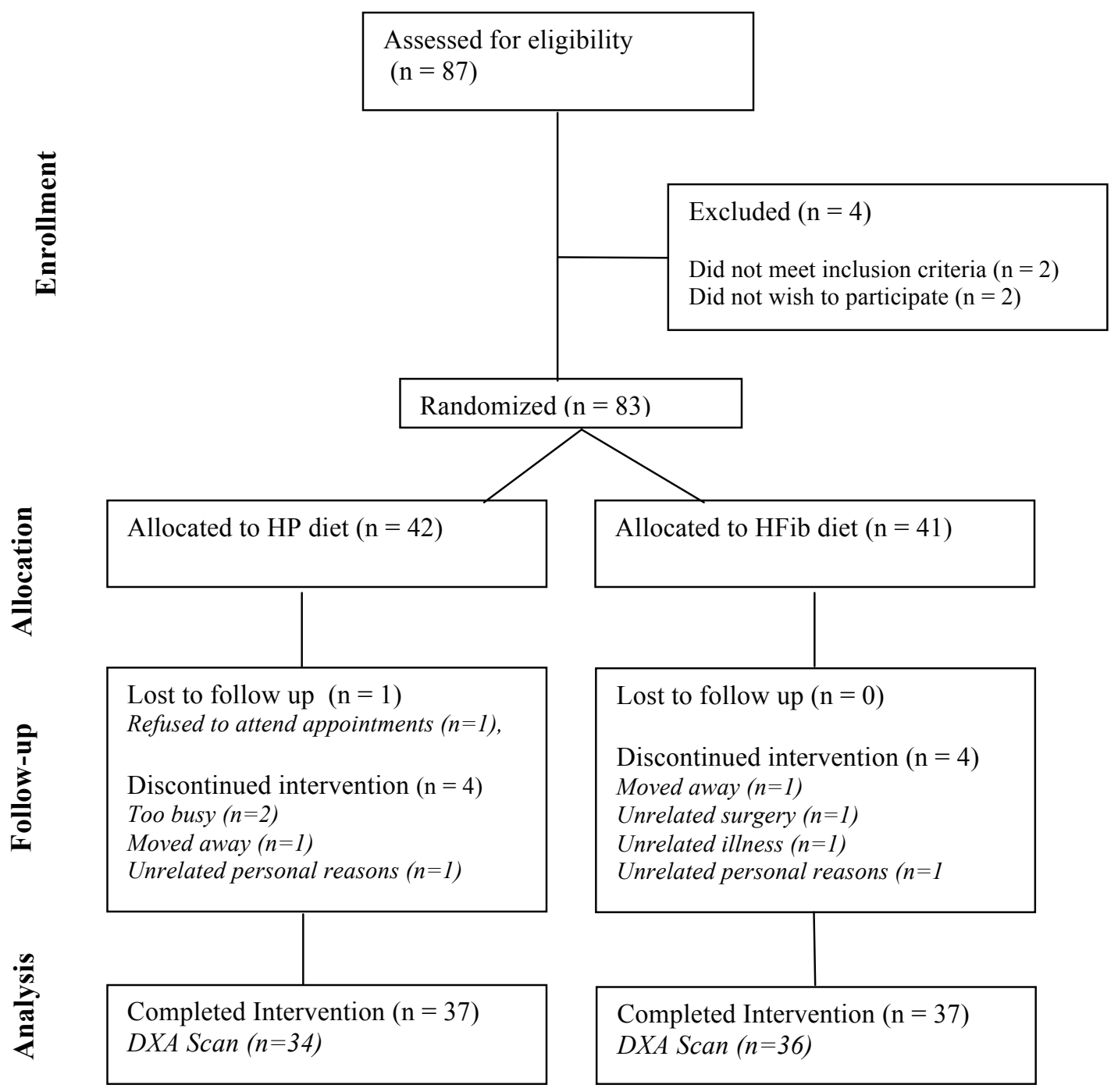

Figure 1 Consort diagram showing flow of participants through the trial

Table 1 Food group recommendations for basic HP and HFib diet plans

\begin{tabular}{|c|c|c|c|}
\hline \multicolumn{2}{|l|}{ HP Diet } & \multicolumn{2}{|l|}{ HFib Diet } \\
\hline Food group & Servings per day & Food group & Servings per day \\
\hline & & $\begin{array}{l}\text { Beans and legumes } \\
\text { (1/2 cup cooked) }\end{array}$ & 1 \\
\hline $\begin{array}{l}\text { Breads cereals \& grains } \\
\text { (approx } 15 \mathrm{~g} \text { carbohydrate) }\end{array}$ & 3 & $\begin{array}{l}\text { High-fiber breads, cereals \& grains } \\
\text { (approx } 15 \mathrm{~g} \text { carbohydrate) }\end{array}$ & 6 \\
\hline $\begin{array}{l}\text { Lean protein foods } \\
\text { (100 g raw weight) }\end{array}$ & 3 & $\begin{array}{l}\text { Lean protein foods } \\
\text { (100 g raw weight) }\end{array}$ & 1 \\
\hline $\begin{array}{l}\text { Low-fat milk and dairy foods } \\
\text { ( } 1 \text { cup or equivalent } \mathrm{kJ} \text { ) }\end{array}$ & 2 & $\begin{array}{l}\text { Low-fat milk and dairy foods } \\
\text { ( } 1 \text { cup or equivalent } \mathrm{kJ} \text { ) }\end{array}$ & 2 \\
\hline $\begin{array}{l}\text { Vegetables } \\
(1 / 2 \text { cup) }\end{array}$ & 5 & $\begin{array}{l}\text { Vegetables } \\
\text { (1/2 cup) }\end{array}$ & 5 \\
\hline $\begin{array}{l}\text { Fruit } \\
\text { (medium size) }\end{array}$ & 2 & $\begin{array}{l}\text { Fruit } \\
\text { (medium size) }\end{array}$ & 2 \\
\hline $\begin{array}{l}\text { Fats and oils } \\
\text { (teaspoon) }\end{array}$ & 3 & $\begin{array}{l}\text { Fats and oils } \\
\text { (teaspoon) }\end{array}$ & 3 \\
\hline Indulgence foods and alcohol (approx $400 \mathrm{~kJ}$ ) & 2 per week & Indulgence foods and alcohol (approx $400 \mathrm{~kJ}$ ) & 2 per week \\
\hline
\end{tabular}


Participants completed a weighed 3-day diet record including 2 non-consecutive weekdays and one weekend day prior to commencing the intervention and at week 8 [20]. They were given instruction on keeping the diet record and were provided with electronic food scales. Dietary intakes of macronutrients and dietary fiber were calculated using the Diet Cruncher for Macintosh V1.2.0 program (Waydown South Software), which uses the New Zealand food composition database (Crop and Food New Zealand). At the end of each dietary data collection day, participants were asked to rate their hunger, fullness, thirst, pre-occupation with thoughts of food, desire to eat and how much they could have eaten over that day on a $10 \mathrm{~cm}$ visual analogue scale (VAS) [21].

To assess whether there was any change in physical activity level during the intervention participants completed the short International Physical Activity Questionnaire (Craig et al., 2003) at baseline and at week 8 . At the final week 8 clinic visit participants completed an exit questionnaire where they were asked to rate their responses to a number of questions relating to the diet they followed on a scale of $0-10$ where 0 was the extreme negative response and 10 was the extreme positive response.

Measurements were made on two occasions (to minimize intrapersonal variation) 2-7 days apart at baseline and at week 8 after a 10-hr overnight fast. Each participant's height, weight, waist circumference and resting blood pressure were measured in duplicate. Height was measured to the nearest millimeter using a stadiometer. Weight was measured in light clothing on electronic scales (Wedderburn) to the nearest $0.05 \mathrm{~kg}$. Waist circumference (WC) was measured to the nearest millimeter using a standard non-stretching tape measure at the midpoint between the lowest part of the rib and highest part of the hip underneath clothing. Resting blood pressure was measured using a manual sphygmomanometer with participants in a seated position after resting for 5 minutes and then repeated 5 minutes later. A fasting blood sample was then taken for the measurement of lipids, glucose, insulin and high-sensitivity Creactive protein (Hs-CRP).

Total body fat mass, lean mass, body fat percentage, and truncal fat mass were assessed by DXA (DPX-L scanner, Lunar Corp, Cincinnati, $\mathrm{OH}$ ) using software version 1.35 (Lunar, Cincinnati, $\mathrm{OH}$ ) at the Dunedin Public Hospital DXA Scanning Unit at baseline and week 8. DXA scanning was limited to participants weighing less than $120 \mathrm{~kg}(\mathrm{n}=70)$.

Whole blood samples were centrifuged at $1650 \mathrm{~g}$ for 15 minutes, then samples were pipetted into polyethylene cryovials and stored at $-80^{\circ} \mathrm{C}$. Laboratory results at all time-points for all subjects were performed in batch within the same assay. Serum insulin and C-peptide were measured using a specific insulin electrochemiluminescence immunoassay (ECLIA) (Roche, Cat. No. 12017547) for the Elecsys ${ }^{\circledR}$ analyzer (Roche Diagnostics, Mannheim, Germany), with a coefficient of variation of $1.5 \%$. Serum total cholesterol and triglycerides (TAG) concentrations were measured enzymatically with Roche kits and calibrators on a Cobas Mira analyzer (Roche Diagnostics, Manheim, Germany), as was plasma glucose (Roche Hexokinase Cat. No. 11447513216). Coefficients of variation were $2.8 \%$ for total-cholesterol, $4.4 \%$ for TAG and $0.5 \%$ for plasma glucose. HDL-cholesterol (HDL C) was measured in the supernatant after precipitation of apolipoprotein B containing lipoproteins with phosphotungstate/magnesium chloride solution [22] with a coefficient of variation of $3.6 \%$. LDL-cholesterol was calculated using the Friedwald equation [23]. High sensitivity C-reactive protein (HS-CRP) was measured by latex enhanced immunoturbidimetric method (Roche CRP(Latex) HS Cat. No. 11972855 216) with a coefficient of variation of $4.3 \%$.

Basal metabolic rate was calculated using HarrisBenedict equations [24]. Insulin sensitivity was estimated by the homeostatic model assessment (HOMA-IR 2) using the HOMA-IR 2 calculator [25] and by the McAuley index [26]. A McAuley index value $\leq 6.3$ was chosen as a cut-off to define insulin resistance. Presence of the metabolic syndrome (MS) was assessed for each subject based on International Diabetes Federation (IDF) cutoffs [27].

The sample size ( $n=35$ per group) was determined on the basis of the number of participants required to detect a $1.4 \mathrm{~kg}(1.8 \mathrm{~kg} \mathrm{SD})$ difference in weight loss with $90 \%$ power at a level of significance of 0.05 . Statistical analysis was performed using the STATA statistical software package 9.0 (Stata, College Station, TX). Data were checked for normality and presented as mean (SD) if normally distributed. Fasting insulin and glucose concentrations were not normally distributed and were thus log-transformed and geometric means (min, max values) are presented. The effect of treatment was analyzed by analysis of covariance with baseline values as a covariate. As this was a proof-of-concept trial data were analyzed on a "per protocol" basis and end of study data were not sought from those who elected to drop out of the study. This is consistent with studies of similar design and duration $[13,14,16,18,19,28,29]$ with which this study is compared.

\section{Results}

Participants were well matched for baseline characteristics (Table 2). Only 6 participants did not meet the IDF criteria for abdominal obesity (WC $\geq 80 \mathrm{~cm}$ ) at baseline. Over $50 \%$ of participants in both groups had elevated total cholesterol concentrations and suboptimal HDL 
Table 2 Baseline demographic and clinical details for all participants randomized to the high protein (HP) or high fiber (HFib) diets

\begin{tabular}{|c|c|c|}
\hline & $\mathrm{HP}$ & HFib \\
\hline$n$ & 42 & 41 \\
\hline Age (years) ${ }^{a}$ & $40.5(12.7)$ & $43.4(9.6)$ \\
\hline BMI $\left(\mathrm{kg} / \mathrm{m}^{2}\right)^{\mathrm{a}}$ & $33.7(4.9)$ & $34.2(4.8)$ \\
\hline Weight $(\mathrm{kg})^{\mathrm{a}}$ & $91.5(15.8)$ & $92.9(15.3)$ \\
\hline Systolic blood pressure $(\mathrm{mm} \mathrm{Hg})^{\mathrm{a}}$ & $126(16)$ & $124(14)$ \\
\hline Diastolic blood pressure $(\mathrm{mm} \mathrm{Hg})^{a}$ & $80(10)$ & $80(10)$ \\
\hline Triglycerides $(\mathrm{mmol} / \mathrm{L})^{\mathrm{a}}$ & $1.47(0.76)$ & $1.42(0.62)$ \\
\hline HDL Cholesterol (mmol/L) $)^{a}$ & $1.24(0.27)$ & $1.28(0.25)$ \\
\hline Fasting plasma glucose $(\mathrm{mmol} / \mathrm{L})^{\mathrm{b}}$ & $5.0(3.8,12.6)$ & $4.9(3.9,6.1)$ \\
\hline Insulin resistant ${ }^{\mathrm{C}}$ & $9(21)$ & $8(20)$ \\
\hline Metabolic syndrome ${ }^{\mathrm{d}}$ & $8(19)$ & $8(20)$ \\
\hline
\end{tabular}

${ }^{\mathrm{a}}$ mean (SD), ${ }^{\mathrm{b}}$ geometric mean (min, max), all other values are $\mathrm{n}(\%) ;{ }^{\mathrm{c}}$

McAuley Index $\leq 6.3 \mathrm{Gffm} / \mathrm{l} ;{ }^{d}$ International Diabetes Federation definition

cholesterol concentrations, $32 \%$ had blood pressure greater than 130/85 or were taking blood pressure lowering medications. Although only $24 \%$ of participants met the IDF criteria for metabolic syndrome $72 \%$ had at least 2 risk defining factors.

Three-day diet records for both baseline and week 8 were returned by 33 and 36 participants in HP and HFib respectively. Reported intakes of total energy and macronutrients at baseline and at week 8 and adjusted differences between the groups are given in Table 3 . The data suggest a remarkable degree of compliance with the dietary advice with regard to macronutrient composition. Energy reduction was significantly greater on HFib than on HP. Particularly notable was the difference between the groups with greater intakes of protein and fat in HP and carbohydrate and dietary fiber on HFib. Despite energy reduction of $1664 \mathrm{~kJ} / \mathrm{d}$ (95\% CI: $792,2536 \mathrm{~kJ} / \mathrm{d}$ ) there was an overall increase in total protein intake of $20 \mathrm{~g} / \mathrm{d}$ (95\% CI: 10, $30 \mathrm{~g} / \mathrm{d}$ ) on HP. This was achieved by increased intake of animal protein $(23 \mathrm{~g} / \mathrm{d}$ [95\% CI: 14, $32 \mathrm{~g} / \mathrm{d}])$ whereas protein from vegetable sources decreased $(-5 \mathrm{~g} / \mathrm{d}$ [95\% CI: $0,9 \mathrm{~g} / \mathrm{d}$ ]).

Participants on the HFib diet reported less hunger ( $\mathrm{p}$ $=0.036$ ) and less pre-occupation with thoughts of food $(\mathrm{p}=0.037)$ than participants on HP. There were no other differences in measures associated with appetite and satiety. There was no evidence of differences between the groups with regard to measures of self-perceived adherence to the diet, dietary compliance, commitment to dietary change, commitment to weight-loss, likelihood of continuing with the diet plan and health during the dietary intervention at the end of the study.

Both diets were associated with appreciable reductions in total body weight, BMI, fat mass with a significantly greater reduction on HP (Additional File 1). There was little change in lean mass on either diet. Reductions in truncal fat and waist circumference were achieved with both diets but there was no evidence of a difference between the two diets.

Blood pressure levels decreased on both diets but the decrease was not statistically significant on HFib. There was statistically significant greater decrease in DBP on HP than on HFib, but not for SBP (Additional File 2). The reduction in DBP was not influenced by the change in weight. However the change in weight was a statistically significant predictor for the reduction in SBP $(\mathrm{p}=$ $0.026)$ and attenuated the effect of diet $(-2.3 \mathrm{~mm} \mathrm{Hg}$; $95 \% \mathrm{CI}-5.8,1.2 \mathrm{~mm} \mathrm{Hg} ; \mathrm{p}=0.197)$. There were reductions in fasting plasma glucose, insulin, total and LDL cholesterol, triglycerides and HS-CRP and increased insulin sensitivity on both diets but there was no significant effect of diet (Additional File 1). HDL-cholesterol was slightly reduced for both diets but there was no difference between diets (Additional File 2).

\section{Discussion}

Our findings clearly show that both the high protein (HP) and the relatively high carbohydrate, high fiber (HFib) diets were associated with appreciable reductions in total body fat, waist circumference, truncal fat, blood pressure, fasting plasma glucose, total and LDL cholesterol and triglyceride, insulin and an increase in insulin sensitivity. These favorable changes occurred without any loss of lean body mass. However, given the aim of this study, the most important findings relate to the comparisons of the magnitude of the benefits observed with the two dietary prescriptions, the HP diet being associated with a significantly greater reduction in adiposity and diastolic blood pressure when compared with HFib. Improvements in systolic blood pressure, triglyceride concentrations and insulin sensitivity measured by the McAuley Index [26] also tended to be more marked on HP than HFib but these differences did not achieve conventional levels of statistical significance.

Previous studies involving comparisons of weight loss on low fat, high protein (LFHP) and LFHC diets fall into two categories: relatively long term comparisons which provide an indication of what might be achieved in practice using current approaches to implementing weight loss regimes, and shorter term studies which should, at least in theory, provide proof of concept. In a systematic review of 13 randomized controlled weight-loss studies lasting at least six months greater weight loss was observed on high protein diets compared with LFHC diets after 6 and 12 months $(-4 \mathrm{~kg}$ and $-1 \mathrm{~kg}$ respectively) [30]. However there was considerable heterogeneity amongst the studies with the largest of the studies [31] finding no difference between the high protein Zone diet and two conventional LFHC diets. Moreover a recent large population 
Table 3 Comparison of changes in dietary intakes ${ }^{a}$

\begin{tabular}{|c|c|c|c|c|}
\hline & Baseline mean (SD) & Week 8 mean (SD) & Difference $(95 \% \mathrm{Cl})^{\mathrm{b}}$ & $P^{c}$ \\
\hline \multicolumn{5}{|l|}{ Energy $(\mathrm{KJ})$} \\
\hline $\mathrm{HP}$ & $8123(2153)$ & 6509 (1351) & & \\
\hline HFib & $8486(2000)$ & $5976(925)$ & $580(9,1150)$ & 0.047 \\
\hline \multicolumn{5}{|l|}{ Protein (\%) } \\
\hline $\mathrm{HP}$ & $18(5)$ & $28(5)$ & & \\
\hline HFib & $18(4)$ & $22(3)$ & $5.6(3.7,7.5)$ & $<0.001$ \\
\hline \multicolumn{5}{|l|}{ Protein (g) } \\
\hline $\mathrm{HP}$ & $82(22)$ & $104(16)$ & & \\
\hline HFib & $86(18)$ & $76(11)$ & $28(21,35)$ & $<0.001$ \\
\hline \multicolumn{5}{|c|}{ Animal protein (g) } \\
\hline $\mathrm{HP}$ & $53(19)$ & $76(14)$ & & \\
\hline HFib & $54(16)$ & $56(14)$ & $21(14,28)$ & $<0.001$ \\
\hline \multicolumn{5}{|l|}{ Fat (\%) } \\
\hline $\mathrm{HP}$ & $33(8)$ & $29(5)$ & & \\
\hline HFib & $31(7)$ & $23(6)$ & $5.8(2.9,8.8)$ & $<0.001$ \\
\hline \multicolumn{5}{|c|}{ Saturated fat (\%) } \\
\hline $\mathrm{HP}$ & $13(3)$ & $9(4)$ & & \\
\hline HFib & $13(4)$ & $6(3)$ & $3.0(1.5,4.7)$ & 0.001 \\
\hline \multicolumn{5}{|l|}{$\mathrm{CHO}(\%)$} \\
\hline $\mathrm{HP}$ & $45(6)$ & $40(6)$ & & \\
\hline HFib & $47(7)$ & $51(6)$ & $-11.1(-14.2,-8.1)$ & $<0.001$ \\
\hline \multicolumn{5}{|c|}{ Dietary fiber (g/day) } \\
\hline $\mathrm{HP}$ & $25(10)$ & $24(8)$ & & \\
\hline HFib & $26(7)$ & $39(11)$ & $-14.2(-18.9,-9.5)$ & $<0.001$ \\
\hline \multicolumn{5}{|c|}{ Soluble dietary fiber (g/day) } \\
\hline $\mathrm{HP}$ & $12(5)$ & $10(3)$ & & \\
\hline $\mathrm{HFib}$ & $12(3)$ & $16(5)$ & $-5.2(-7.2,-3.2)$ & $<0.001$ \\
\hline \multicolumn{5}{|c|}{ Insoluble dietary fiber (g/day) } \\
\hline $\mathrm{HP}$ & $13(5)$ & $14(5)$ & & \\
\hline HFib & $14(5)$ & $23(7)$ & $-8.9(-12.0,-5.9)$ & $<0.001$ \\
\hline \multicolumn{5}{|l|}{ Sodium (mg/d) } \\
\hline $\mathrm{HP}$ & 2479 (909) & $2049(677)$ & & \\
\hline HFib & $2745(840)$ & $2125(498)$ & $-15(-264,294)$ & 0.912 \\
\hline \multicolumn{5}{|l|}{ Alcohol (g) } \\
\hline $\mathrm{HP}$ & $6(9)$ & $3(5)$ & & \\
\hline HFib & $5(9)$ & $2(5)$ & $0.4(-1.6,2.4)$ & 0.693 \\
\hline
\end{tabular}

${ }^{a}$ High protein diet (HP) $n=33$ records, and high fiber diet (HFib), $n=36$ records;

${ }^{b}$ difference between HP and HFib diets estimated by ANCOVA with adjustment for baseline value;

${ }^{c} \mathrm{p}$-value for the difference between the HP and HFib diets

study by Sacks et al. that compared weight-loss diets varying only in the proportions of fat, protein and carbohydrate showed each diet to be equally successful in facilitating and maintaining weight loss over a twoyear follow-up period [32]. High rates of attrition and difficulties in assessing long-term compliance make it difficult to conclude with any certainty that high protein diets are indeed superior to LFHC diets in longerterm studies involving free-living individuals. Thus shorter-term "proof of concept" comparisons are required to resolve these issues.
Such studies have generally found comparable, rather than greater, reductions in weight and body fat when comparing isocaloric, energy restricted LFHP diets with LFHC diets in interventions lasting $12-16$ weeks [11,13,14,18,19,33-35]. However subgroup analyses of some of these studies suggested greater reduction in weight and body fat on LFHP in women with raised triglycerides [18] and obese women with diabetes [36]. Two studies, one of which compared a very high protein (45\% TE) diet with a LFHC diet over 4 weeks [17] and the other a 12 -wk study in which the high protein diet included an 
initial 2-week high fat, high protein phase [29], have reported significantly greater weight and fat loss on high protein compared LFHC diets. The differences in experimental design, macronutrient distribution and nature of carbohydrate preclude definitive conclusions from the previously published trials as to whether, even in the short term, relatively high protein intakes confer weight loss and metabolic benefits over relatively high carbohydrate diets rich in dietary fiber derived principally from wholegrains, vegetables and fruits. Our findings suggest that this is indeed the case, at least over a period of 8-wks.

In dietary intervention studies, ranging from 4 weeks to 12 months, participants on ad-libitum high protein diets have reported lower energy consumption than those on other diets and achieved greater weight loss $[12,37,38]$. Thus high protein diets may facilitate weight loss because subjects spontaneously consume less energy than subjects consuming comparative diets. Only a limited number of studies have examined this issue in the context of metabolically controlled hypocaloric diets. These studies reported increased satiety on high protein versus standard protein diets but this did not translate into a greater reduction of energy intake or more weight loss $[11,35,39]$. Participants on the HP diet in our study reported greater hunger, more preoccupation with thoughts of food and higher energy intakes than participants on HFib yet lost more weight. Although selfreported energy intakes are notoriously unreliable it would appear that satiation was not a major factor explaining the greater weight loss on HP. The fact that dietary fiber is also associated with increased satiety and fullness [40] may explain these observations.

Weight loss diets have often been associated with some loss of lean body mass in addition to the reduction of fat mass. High protein diets have been associated with retention of lean body mass (LBM) when compared with high carbohydrate diets $[16,19,33,41]$ even when there has been no difference in change in total body weight. A meta-regression analysis of weight loss studies comparing low carbohydrate high protein diets with LFHC diets suggested that protein intakes greater than $1.05 \mathrm{~g} / \mathrm{kg} / \mathrm{d}$ were associated with greater retention of fat free mass compared with lower protein intakes [41]. Thus our findings confirm, once again, the potential of high protein diets to facilitate retention of LBM although the HP diet provided no additional benefit compared with the HFib diet.

Weight loss has been clearly associated with a decrease in blood pressure. A meta-analysis of studies lasting more than 8 weeks examining the effect of weight loss on blood pressure estimated that a $1 \mathrm{~kg}$ reduction in weight was associated with reductions of $1.05 \mathrm{~mm} \mathrm{Hg}$ reduction for SBP and $0.92 \mathrm{~mm} \mathrm{Hg}$ for DBP [42]. However weight loss explained little of the difference in blood pressure observed on our diets in our statistical models, thus suggesting that there was a specific blood pressure-lowering effect due to protein. Protein intake, from derived primarily from both plant and animal sources, has been associated with lower blood pressure in other dietary intervention studies in the absence of weight loss [35,43-45].

Earlier studies suggesting deleterious effects of high carbohydrate diets relative to high-protein diets may have resulted from the nature of carbohydrate and dietary fiber consumed [15,46]. Participants on HFib in our study chose appropriate carbohydrates and achieved high fiber intakes, and consequently achieved favourable changes in lipids and insulin sensitivity that were comparable with improvements on HP.

Epidemiological studies have suggested that high meat and animal protein intakes are associated with increased risk of insulin resistance syndrome [47] and diabetes $[48,49]$. Consequently there has been interest in diets emphasizing plant protein as a means to increase overall protein intakes and potentially achieve even greater metabolic benefits than high protein diets emphasizing animal protein $[35,43]$. Our findings, however, show no evidence of deleterious effects on metabolic risk factors of a substantial increase in animal protein on the HP diet.

The fact that our participants were relatively healthy, despite being overweight, may have limited our ability to show the potential of the two diets to modify metabolic risk factors. There is evidence to suggest that macronutrient composition may have a greater influence on metabolic responses in individuals with certain metabolic risk factors compared to those without such risk factors $[50,51]$. While this evidence suggests that diets relatively higher in protein may be more beneficial for high-risk individuals than high carbohydrate diets, direct comparisons between high protein and high carbohydrates diets emphasizing high fiber, minimally processed foods have not been made. Indeed other studies suggest that high fiber diets improve insulin sensitivity and other cardiovascular risk factors in individuals with hyperinsulinaemia and diabetes in comparison with diets high in refined carbohydrates $[52,53]$. Thus the generalisability of our research to very high risk individuals, such as those with diabetes, is uncertain.

The relatively short duration of our study may also be considered to be a limitation. Longer-term studies indicate that short-term benefits associated with reduced carbohydrate intakes are not sustained over the longer-term but this is largely explained by subjects reverting to their usual dietary patterns $[30,32,54]$. This dietary intervention trial was intended to be a "proof-of-concept" study with the clear objective being to compare the potential of weight reducing diets differing in macronutrient composition to influence measures of adiposity and metabolic risk factors. In this respect the remarkable extent to which participants 
complied with the dietary prescriptions and the use of DXA as a relatively sensitive measure for assessing adiposity are major strengths. Clearly these findings relate most directly to overweight and obese women, but there is only limited evidence to suggest that men might respond differently [36].

\section{Conclusions}

We believe that we have demonstrated modest overall benefit when a relatively high protein weight-reducing diet has been compared with a high-fiber diet. However our findings suggest that considerable benefit may also accrue from a diet that is rich in wholegrain cereals, legumes, intact fruits and vegetables and low in saturated fat. Earlier studies suggesting deleterious effects of high carbohydrate diets relative to high protein diets may have resulted from the nature of carbohydrate and dietary fiber consumed $[15,46]$. On the basis of these findings it seems reasonable to conclude that that while a high protein diet might be the preferred prescription for weight reduction, a relatively high carbohydrate diet offers an alternative for those who, because of cost or dietary preferences, choose not to increase protein intake. Given that the present study was a relatively short-term proof-of-concept study and longer-term studies have generated equivocal results, novel approaches are needed to examine ways of encouraging long-term adherence to dietary advice before conclusions can be drawn with regard to the long-term importance of macronutrient composition.

\section{Additional material}

Additional file 1: Table S1: Comparison of body composition outcomes for all participants completing the study. Results table that does not fit to a single portrait page width.

Additional file 2: Table S2: Comparison of biochemical measures for for all participants completing the study. Results table that does not fit to a single portrait page width.

\begin{abstract}
Acknowledgements
We thank M. Waldron and S. Vorgers, who were the study research nurses, M. Harper and A. Duncan who undertook the laboratory analyses and Prof A. Goulding and A. Grant who carried out the DXA scans.
\end{abstract}

\section{Author details}

1 Department of Human Nutrition, University of Otago, PO Box 56, Dunedin 9054, New Zealand. '2Department of Preventive and Social Medicine, University of Otago, PO Box 56, Dunedin 9054, New Zealand. ${ }^{3}$ Edgar National Centre for Diabetes Research, University of Otago, PO Box 56, Dunedin 9054, New Zealand. ${ }^{4}$ Riddet Institute, Private Bag 11 222, Palmerston North 4442, New Zealand.

\section{Authors' contributions}

LAT was the main author of manuscript and participated in the study design, execution and data collection, and carried out the statistical analyses. MTL contributed to the execution of the study, data collection, analysis and interpretation. SMW supervised the statistical analyses and assisted with the preparation of the manuscript. RCB and JM were doctoral supervisors of LAT and participated in the study conception, design, interpretation and preparation of the manuscript. All authors read and approved the final manuscript.

\section{Competing interests}

$J M$ and LAT have received funding from Fonterra Co-operative Group Ltd which has facilitated this and other projects. Fonterra have had no involvement in the design, analysis, interpretation or reporting of the data. None of the authors had a conflict of interest.

Received: 11 October 2010 Accepted: 28 April 2011 Published: 28 April 2011

\section{References}

1. Parikh P, McDaniel MC, Ashen MD, Miller Jl, Sorrentino M, Chan V Blumenthal RS, Sperling LS: Diets and Cardiovascular Disease: An Evidence-Based Assessment. J Am Coll Cardiol 2005, 45:1379-1387.

2. Nield $L$, Summerbell CD, Hooper $L$, Whittaker $V$, Moore H: Dietary advice for the prevention of type 2 diabetes mellitus in adults. Cochrane Database Syst Rev 2008, CD005102.

3. Serra-Majem L, Roman B, Estruch R: Scientific Evidence of Interventions Using the Mediterranean Diet: A Systematic Review. Nutrition Reviews 2006, 64:S27-S47.

4. Yancy WS Jr, Olsen MK, Guyton JR, Bakst RP, Westman EC: A lowcarbohydrate, ketogenic diet versus a low-fat diet to treat obesity and hyperlipidemia: a randomized, controlled trial. Ann Intern Med 2004, 140:769-777.

5. Samaha FF, lqbal N, Seshadri $P$, Chicano KL, Daily DA, McGrory J, Williams T, Williams M, Gracely EJ, Stern L: A low-carbohydrate as compared with a low-fat diet in severe obesity. N Engl J Med 2003, 348:2074-2081.

6. Atkins RC: Atkins' new diet revolution. New York, NY 10017: M. Evans \& Co; 2002, Revised.

7. Sears B, Lawren B: The Zone: A Dietary Road Map to Lose Weight Permanently: Reset Your Genetic Code: Prevent Disease: Achieve Maximum Physical Performance. New York, NY 10022: HarperCollins; 11995.

8. Noakes M, Clifton PM, CSIRO: The CSIRO total wellbeing diet. Camberwell, Vic.: Penguin; 2005.

9. Westman EC, Feinman RD, Mavropoulos JC, Vernon MC, Volek JS, Wortman JA, Yancy WS, Phinney SD: Low-carbohydrate nutrition and metabolism. Am J Clin Nutr 2007, 86:276-284.

10. Hu FB: Protein, body weight, and cardiovascular health. Am J Clin Nutr 2005, 82:242S-247S.

11. Layman DK, Boileau RA, Erickson DJ, Painter JE, Shiue H, Sather C, Christou DD: A Reduced Ratio of Dietary Carbohydrate to Protein Improves Body Composition and Blood Lipid Profiles during Weight Loss in Adult Women. J Nutr 2003, 133:411-417.

12. Skov AR, Toubro S, Ronn B, Holm L, Astrup A: Randomized trial on protein vs carbohydrate in ad libitum fat reduced diet for the treatment of obesity. Int J Obes Relat Metab Disord 1999, 23:528-536.

13. Johnston CS, Tjonn SL, Swan PD: High-Protein, Low-Fat Diets Are Effective for Weight Loss and Favorably Alter Biomarkers in Healthy Adults. J Nutr 2004, 134:586-591.

14. Lasker DA, Evans EM, Layman DK: Moderate carbohydrate, moderate protein weight loss diet reduces cardiovascular disease risk compared to high carbohydrate, low protein diet in obese adults: A randomized clinical trial. Nutr Metab (Lond) 2008, 5:30.

15. Mann J: Dietary carbohydrate: relationship to cardiovascular disease and disorders of carbohydrate metabolism. Eur J Clin Nutr 2007, 61(Suppl 1): S100-111.

16. Piatti PM, Monti F, Fermo I, Baruffaldi L, Nasser R, Santambrogio G, Librenti MC, Galli-Kienle M, Pontiroli AE, Pozza G: Hypocaloric high-protein diet improves glucose oxidation and spares lean body mass: comparison to hypocaloric high-carbohydrate diet. Metabolism 1994, 43:1481-1487.

17. Baba NH, Sawaya S, Torbay N, Habbal Z, Azar S, Hashim SA: High protein vs high carbohydrate hypoenergetic diet for the treatment of obese hyperinsulinemic subjects. Int J Obes Relat Metab Disord 1999, 23:1202-1206. 
18. Noakes M, Keogh JB, Foster PR, Clifton PM: Effect of an energy-restricted, high-protein, low-fat diet relative to a conventional high-carbohydrate, low-fat diet on weight loss, body composition, nutritional status, and markers of cardiovascular health in obese women. Am J Clin Nutr 2005, 81:1298-1306.

19. Farnsworth E, Luscombe ND, Noakes M, Wittert G, Argyiou E, Clifton PM: Effect of a high-protein, energy-restricted diet on body composition, glycemic control, and lipid concentrations in overweight and obese hyperinsulinemic men and women. Am J Clin Nutr 2003, 78:31-39.

20. Gibson RS: Principles of Nutrtional Assessment. New York: Oxford Univeristy Press; 22005.

21. Stubbs RJ, Hughes DA, Johnstone AM, Rowley E, Reid C, Elia M, Stratton R, Delargy $H$, King N, Blundell JE: The use of visual analogue scales to assess motivation to eat in human subjects: a review of their reliability and validity with an evaluation of new hand-held computerized systems for temporal tracking of appetite ratings. $\mathrm{Br} J$ Nutr 2000, 84:405-415.

22. Assmann G, Schriewer H, Schmitz G, Hagele EO: Quantification of highdensity-lipoprotein cholesterol by precipitation with phosphotungstic acid/MgCl2. Clin Chem 1983, 29:2026-2030.

23. Friedewald WT, Levy RI, Fredrickson DS: Estimation of the concentration of low-density lipoprotein cholesterol in plasma, without use of the preparative ultracentrifuge. Clin Chem 1972, 18:499-502.

24. Harris JA, Benedict FG: A Biometric Study of Human Basal Metabolism. Proc Natl Acad Sci USA 1918, 4:370-373.

25. Levy JC, Matthews DR, Hermans MP: Correct homeostasis model assessment (HOMA) evaluation uses the computer program. Diabetes Care 1998, 21:2191-2192.

26. McAuley KA, Williams SM, Mann JI, Walker RJ, Lewis-Barned NJ, Temple LA, Duncan AW: Diagnosing insulin resistance in the general population. Diabetes Care 2001, 24:460-464.

27. Alberti KG, Zimmet $P$, Shaw J: The metabolic syndrome-a new worldwide definition. Lancet 2005, 366:1059-1062.

28. Layman DK, Evans EM, Erickson D, Seyler J, Weber J, Bagshaw D, Griel A, Psota T, Kris-Etherton P: A moderate-protein diet produces sustained weight loss and long-term changes in body composition and blood lipids in obese adults. J Nutr 2009, 139:514-521.

29. Aude YW, Agatston AS, Lopez-Jimenez F, Lieberman EH, Marie A, Hansen M, Rojas G, Lamas GA, Hennekens CH: The national cholesterol education program diet vs a diet lower in carbohydrates and higher in protein and monounsaturated fat: a randomized trial. Arch Intern Med 2004, 164:2141-2146.

30. Hession M, Rolland C, Kulkarni U, Wise A, Broom J: Systematic review of randomized controlled trials of low-carbohydrate vs. low-fat/low-calorie diets in the management of obesity and its comorbidities. Obesity Reviews 2009, 10:36-50

31. Gardner CD, Kiazand A, Alhassan S, Kim S, Stafford RS, Balise RR, Kraemer HC, King AC: Comparison of the Atkins, Zone, Ornish, and LEARN diets for change in weight and related risk factors among overweight premenopausal women: the A TO Z Weight Loss Study: a randomized trial. JAMA 2007, 297:969-977.

32. Sacks FM, Bray GA, Carey VJ, Smith SR, Ryan DH, Anton SD, McManus K, Champagne CM, Bishop LM, Laranjo N, Leboff MS, Rood JC, de Jonge L, Greenway FL, Loria CM, Obarzanek E, Williamson DA: Comparison of weight-loss diets with different compositions of fat, protein, and carbohydrates. N Engl J Med 2009, 360:859-873.

33. Leidy HJ, Carnell NS, Mattes RD, Campbell WW: Higher Protein Intake Preserves Lean Mass and Satiety with Weight Loss in Pre-obese and Obese Women. Obesity 2007, 15:421-429.

34. Krauss RM, Blanche PJ, Rawlings RS, Fernstrom HS, Williams PT: Separate effects of reduced carbohydrate intake and weight loss on atherogenic dyslipidemia. Am J Clin Nutr 2006, 83:1025-1031.

35. Jenkins DJ, Wong JM, Kendall CW, Esfahani A, Ng WW, Leong TC, Faulkner DA, Vidgen E, Greaves KA, Paul G, Singer W: The effect of a plantbased low-carbohydrate ("Eco-Atkins") diet on body weight and blood lipid concentrations in hyperlipidemic subjects. Arch Intern Med 2009, 169:1046-1054

36. Parker B, Noakes M, Luscombe N, Clifton P: Effect of a high-protein, highmonounsaturated fat weight loss diet on glycemic control and lipid levels in type 2 diabetes. Diabetes Care 2002, 25:425-430

37. McAuley KA, Hopkins CM, Smith KJ, McLay RT, Williams SM, Taylor RW Mann Jl: Comparison of high-fat and high-protein diets with a high- carbohydrate diet in insulin-resistant obese women. Diabetologia 2005, 48:8-16.

38. Weigle DS, Breen PA, Matthys CC, Callahan HS, Meeuws KE, Burden VR, Purnell JQ: A high-protein diet induces sustained reductions in appetite, ad libitum caloric intake, and body weight despite compensatory changes in diurnal plasma leptin and ghrelin concentrations. Am J Clin Nutr 2005, 82:41-48.

39. Luscombe-Marsh ND, Noakes M, Wittert GA, Keogh JB, Foster P, Clifton PM: Carbohydrate-restricted diets high in either monounsaturated fat or protein are equally effective at promoting fat loss and improving blood lipids. Am J Clin Nutr 2005, 81:762-772.

40. Pereira MA, Ludwig DS: Dietary fiber and body-weight regulation. Observations and mechanisms. Pediatr Clin North Am 2001, 48:969-980.

41. Krieger JW, Sitren HS, Daniels MJ, Langkamp-Henken B: Effects of variation in protein and carbohydrate intake on body mass and composition during energy restriction: a meta-regression 1. Am J Clin Nutr 2006, 83:260-274.

42. Neter JE, Stam BE, Kok FJ, Grobbee DE, Geleijnse JM: Influence of weight reduction on blood pressure: a meta-analysis of randomized controlled trials. Hypertension 2003, 42:878-884

43. Appel LJ, Sacks FM, Carey VJ, Obarzanek E, Swain JF, Miller ER, Conlin PR, Erlinger TP, Rosner BA, Laranjo NM, Charleston J, McCarron P, Bishop LM: Effects of protein, monounsaturated fat, and carbohydrate intake on blood pressure and serum lipids: results of the OmniHeart randomized trial. JAMA 2005, 294:2455-2464.

44. Hodgson JM, Burke V, Beilin LJ, Puddey IB: Partial substitution of carbohydrate intake with protein intake from lean red meat lowers blood pressure in hypertensive persons. Am J Clin Nutr 2006, 83:780-787.

45. He J, Gu D, Wu X, Chen J, Duan X, Whelton PK: Effect of soybean protein on blood pressure: a randomized, controlled trial. Ann Intern Med 2005, 143:1-9.

46. Layman DK, Clifton P, Gannon MC, Krauss RM, Nuttall FQ: Protein in optimal health: heart disease and type 2 diabetes. Am J Clin Nutr 2008, 87:1571S-1575

47. Pereira MA, Jacobs DR Jr, Van Horn L, Slattery ML, Kartashov Al, Ludwig DS: Dairy consumption, obesity, and the insulin resistance syndrome in young adults: the CARDIA Study. JAMA 2002, 287:2081-2089.

48. Sluijs I, Beulens JW, van der AD, Spijkerman AM, Grobbee DE, van der Schouw YT: Dietary intake of total, animal, and vegetable protein and risk of type 2 diabetes in the European Prospective Investigation into Cancer and Nutrition (EPIC)-NL study. Diabetes Care 2010, 33:43-48.

49. Song Y, Manson JE, Buring JE, Liu S: A prospective study of red meat consumption and type 2 diabetes in middle-aged and elderly women: the women's health study. Diabetes Care 2004, 27:2108-2115.

50. Shai I, Schwarzfuchs D, Henkin Y, Shahar DR, Witkow S, Greenberg I, Golan R, Fraser D, Bolotin A, Vardi H, Tangi-Rozental O, Zuk-Ramot R, Sarusi B, Brickner D, Schwartz Z, Sheiner E, Marko R, Katorza E, Thiery J, Fiedler GM, Bluher M, Stumvoll M, Stampfer MJ: Weight loss with a lowcarbohydrate, Mediterranean, or low-fat diet. N Engl J Med 2008, 359:229-241

51. Cornier M-A, Donahoo WT, Pereira R, Gurevich I, Westergren R, Enerback S, Eckel PJ, Goalstone ML, Hill JO, Eckel RH, Draznin B: Insulin Sensitivity Determines the Effectiveness of Dietary Macronutrient Composition on Weight Loss in Obese Women. Obesity 2005, 13:703-709.

52. Pereira MA, Jacobs DR Jr, Pins JJ, Raatz SK, Gross MD, Slavin JL, Seaquist ER: Effect of whole grains on insulin sensitivity in overweight hyperinsulinemic adults. Am J Clin Nutr 2002, 75:848-855.

53. Katcher HI, Legro RS, Kunselman AR, Gillies PJ, Demers LM, Bagshaw DM, Kris-Etherton PM: The effects of a whole grain-enriched hypocaloric diet on cardiovascular disease risk factors in men and women with metabolic syndrome. Am J Clin Nutr 2008, 87:79-90.

54. McAuley KA, Smith KJ, Taylor RW, McLay RT, Williams SM, Mann Jl: Longterm effects of popular dietary approaches on weight loss and features of insulin resistance. Int J Obes (Lond) 2006, 30:342-349.

doi:10.1186/1475-2891-10-40

Cite this article as: Te Morenga et al:: Comparison of high protein and high fiber weight-loss diets in women with risk factors for the metabolic syndrome: a randomized trial. Nutrition Journal 2011 10:40. 